\title{
Highlights of the
}

\section{Social Security Amendments of 1958}

$\mathrm{T}$ HE SOCIAL SECURITY Amendments of $1958(1 a)$, signed by the President on August 28, 1958, will affect almost every American family both in benefits and in taxes. They will implement further the basic principles of the public assistance titles of the Social Security Act as expressed by Congress in the amendments enacted in 1956 :

1. To help the aged attain self-care.

2. To help the blind and disabled attain selfsupport or self-care.

3. To help those responsible for dependent children to maintain and strengthen family life.

The amendments provide for increased benefits to old-age, survivors, and disability insurance recipients; higher social security taxes for workers and their employers and for the self-employed; an increase in the maximum earnings base for social security taxes and benefits; changes in eligibility requirements which will extend coverage to many individuals and families particularly in disability payments; increased flexibility of Federal participation in State-operated public assistance programs for the aged, blind and disabled, and for dependent children; increased appropriations authorized for each of the three programs under title $\mathrm{V}$ of

This report was prepared by Lucy M. Kramer, research analyst in the Division of Public Health Methods, Public Health Service, largely from materials of the Social Security Administration, and in consultation with members of its staff. the Social Security Act (maternal and child health, crippled children's, and child welfare services); and extension of welfare services to children in urban areas on a par with children in rural areas.

Provision is also made for the establishment of advisory councils on child welfare services and on public assistance, similar to the existing Advisory Council on Social Security Financing.

The major amendments are summarized in the following paragraphs.

\section{Old-Age, Survivors, and Disability Insurance}

The amendments of 1958 provide for a revision of the financial basis of the old-age, survivors, and disability insurance program through increased benefits and contributions. In addition to strengthening the financial basis of the system, the amendments extend protection for the disabled through benefit coverage for dependents and through the elimination of certain restrictions, extension of the retroactive period for application for disability benefits, and modification of the work requirements for eligibility.

\section{Higher Benefits}

Effective with benefit checks for January 1959 (which will be mailed early in February) 12 million men, women, and children now receiving monthly old-age, survivors, and disability benefits will receive automatic increases of about 7 percent. 
Retired workers aged 65 or over now receiving benefits ranging from $\$ 30$ to $\$ 108.50$ will receive $\$ 33$ to $\$ 116$. For a retired worker and spouse the maximum will be increased from $\$ 162.80$ to $\$ 174$.

Payments to dependents and survivors will be increased by about 7 percent also, with maximum payment to a family increased from $\$ 200$ to $\$ 254$. When several family members receive payments, each may not get the full 7 percent increase.

Disability insurance benefits to totally disabled workers aged 50-65, payable in amounts comparable to old-age insurance benefits, will also be increased by about 7 percent. Disability insurance benefits have been payable under the social security program since July 1957. About 225,000 persons with extended, total disabilities were receiving these benefits as of August 31, 1958.

The House Report on the Social Security Amendments of 1958 noted that wages had increased 12 percent and prices 8 percent since the last benefit increase was put into effect in 1954, and that old-age, survivors, and disability insurance benefits were a major source of income for most beneficiaries. "Clearly, since their benefits are such an important part of their income, the beneficiaries will be in real need if benefit amounts are not adjusted in the light of rising prices, wages, and levels of living" (2a).

\section{Higher Taxes}

Beginning in January 1959, the social security tax will increase from $21 / 4$ to $21 / 2$ percent for both employers and employees. The tax for self-employed persons will go up from $33 / 8$ percent to $33 / 4$ percent, beginning with 1959 earnings. Scheduled increases-1/4 of 1 percent for employers and workers and $3 / 8$ of 1 percent for the self-employed-will take place every 3 years instead of every 5 years as in the past, and will reach a maximum of $41 / 2$ and $63 / 4$ percent, respectively, in 1969 instead of 1975 (1b, 2b).

Effective January 1, 1959, the maximum annual earnings base for purposes of taxes and credit towards social security benefits will be increased from $\$ 4,200$ to $\$ 4,800$. As a result of the change, the maximum retirement benefit will eventually be $\$ 127$ per month for a single worker and $\$ 190.50$ for a married worker and spouse 65 years of age or older.

The House Ways and Means Committee believed the rise in earnings levels made such an increase in tax base appropriate. "If the earnings base is not increased as wages rise, the wage-related character of the system will be weakened and eventually lost. In 1950 about 64 percent of regularly employed men would have had all their wages credited toward benefits under the $\$ 3,600$ base that was adopted in that year. The $\$ 4,200$ earnings base adopted in 1954 would have covered all the wages of about 56 percent of such workers. In 1957 only 43 percent had all their wages credited; about 56 percent would have received full credit under a $\$ 4,800$ base. An increase to $\$ 4,800$ would restore the situation which prevailed in 1954 and thus, in our opinion, would be a conservative adjustment to the rise in wages that has taken place" (2a).

\section{Improvements in Disability Protection}

For the first time, dependents of disabled workers who are receiving disability insurance benefits will receive social security payments. These payments are similar to those now provided for dependents of retired workers. Those eligible are wives and dependent husbands who have reached retirement age, unmarried dependent children (including sons or daughters disabled since childhood), and wives who have an entitled child in their care. As of September 1958 there were about 180,000 dependents of disability insurance beneficiaries who could become eligible for these monthly benefits.

The Social Security Amendments of 1958 eliminated the "disability benefits offset provision," of the law. Before the elimination of this provision, monthly social security disability payments (including childhood disability benefits) were reduced by the amount of any periodic benefit payable on account of disability under any other Federal program (except veteran's compensation) or a State workmen's compensation system. As of July 1958, about 40,000 disability insurance benefits (and about 1,000 childhood disability benefits) were either reduced or withheld as a result of this offset. Beginning in August 1958, the disabled can 
receive the full amount of their social security benefits irrespective of any other payments based on disability. The House Ways and Means Committee stated (2c) that, since disability payments under the social security system are intended to provide basic protection against income loss from disabling illness, "it is undesirable, and incompatible with the purposes of the program, to reduce these benefits on account of disability benefits that are payable under other programs."

Another important amendment affecting the disabled changed the work requirements for both cash disability benefits and the disability freeze. The disability freeze preserves the disabled worker's future social security rights to benefits under the old-age and survivors insurance program. His wage record is frozen as of the date of disability. He is assured protection in the amount of benefits he receives at a later date.

Before the changes, to be eligible for either disability benefits or the disability freeze, the disabled worker must have worked in employment covered by social security for at least 5 years during the 10 years preceding disability, of which $11 / 2$ years must have been within the immediately preceding 3 -year period. To be eligible for disability benefits, the worker must also have been fully insured, that is, he must have made social security contributions for half the 40 quarters in a 10-year working period prior to disability. The requirement of $11 / 2$ years out of 3 years, as applied to both the disability insurance benefits and the freeze, was eliminated, and fully insured status was added as a requirement for eligibility for the freeze. Thus, as a result of the amendments, to qualify for disability benefits or the freeze, the worker must be fully insured and must have about 5 years of covered work during the 10-year period that ends with the onset of his disability. As a result of the changed work requirements, about 35,000 persons who could not qualify for disability insurance benefits under the previous requirements can, upon filing application, become immediately eligible for benefits. In addition, about 15,000 persons can qualify immediately for a disability freeze.

The deadline for filing fully retroactive applications for the disability freeze-that is, ap- plications which permit a disability freeze to be established as early as the actual onset of disability-was extended for 3 years, from June 30,1958 , to June 30,1961 . Under prior law, a disability freeze based on an application filed after June 30, 1958, could begin no earlier than 1 year before application. The postponement of the deadline for filing fully retroactive freeze applications made it possible (if applications are filed) for about 30,000 additional disabled workers to become immediately eligible for disability insurance benefits and an additional 10,000 to become immediately eligible for the freeze.

The amendments also provide for retroactive payment of disability insurance benefits for as many as 12 months before the month in which application is filed for these benefits. Applications for disability insurance benefits are thus accorded the same retroactive status as applications for all other types of monthly benefits under the program.

\section{Public Assistance}

The Federal matching formula for public assistance has been changed in three major respects, which, in addition to affecting payments for income and maintenance, have an impact on medical services for public assistance beneficiaries and are of particular significance to public health.

\section{Average Maximum}

Effective October 1, 1958, the matchable maximum for Federal contribution to the States, for their aged, blind, and disabled programs, has been set at $\$ 65$ per month per recipient, with the matchable maximum determined by averaging the combined money and vendor payments in each State for the total number of recipients. For aid to dependent children, the maximum has been set at $\$ 30$, with the matchable maximum also determined by an average based on the total number of recipients. The provision for a lower maximum of Federal participation ( $\$ 23$ ) for additional dependent children after the first in the same family has been eliminated, so that the average maximum is applicable to all children and to the needy adult caring for them. 
The effect of this amendment will be to increase the Federal share of assistance payments. With only 1 or 2 exceptions, States had not been receiving the maximum money payments available under the prior limit of $\$ 60$ for Federal participation. Under the new provisions, the maximum total amount in which the Federal Government participates will be increased, and, for States with low per capita income, the percent of Federal participation will also be increased. In the event that families or persons are responsible for more than one dependent child, States will be provided with additional Federal funds that may be used to increase assistance payments. In addition, administrative and fiscal procedures will be simplified under this amendment.

For payments to the aged, blind and disabled, the Federal share will still be $4 / 5$ of the first $\$ 30$ per recipient, but for the remainder, up to a new average maximum of $\$ 65$, the Federal participation will vary with State and national per capita income. For aid to dependent children programs, the Federal share remains $14 / 17$ of the first $\$ 17$ per recipient, but for the remainder, up to a new average maximum of $\$ 30$, it will also vary with per capita income.

\section{Variable Grants}

Effective October 1, 1958, the previous 50-50 matching of Federal funds above the first part of the average amount per recipient, but within the overall limits, has been changed to a variable range of 50 to 65 percent, based on the average per capita income of a State during the 3 most recent calendar years. This would limit Federal participation to 50 percent for those States whose per capita income is equal to or above the national average for the same period, and allow an upward range to 65 percent for those States whose per capita income is below the national average.

The present law requires the Secretary of the Department of Health, Education, and Welfare to promulgate in alternate even numbered years the Federal percentage of participation for each State.

The Federal percentage of financial participation in State public assistance expenditures, following the initial promulgation (3), is shown in table 1 for the period October 1,1958 , to June 30, 1961.

For the new Federal matching procedure, a research note prepared by the Division of Program Research of the Social Security Administration summarizes estimates of total and per capita personal income for 1957 alone and for 1955-57 (4). It tabulates by States the ratio of State to national per capita income in order of magnitude for 1957, and compares the results with the 3-year average.

Per capita personal income in 1957 averaged $\$ 2,027$ for the continental United States, 3 percent above the average for 1956 of $\$ 1,961$. By State, the 1957 average per capita income varied from $\$ 958$ in Mississippi to $\$ 2,821$ in Connecticut. The range of $\$ 1,863$ between the lowest and highest income State went from more than 50 percent below the national average to 39 percent above. When the Federal formula grant is applied in terms of 3-year averages, the order of rank changes with lessening of annual fluctuation. Mississippi remains lowest of the bottom 12 States with an average of $\$ 968$. Connecticut no longer ranks first but is second in the top 12 , with an average of $\$ 2,678$. Delaware is first with $\$ 2,744$. Twenty States retain their rank; the rest shift.

The House Ways and Means Committee expressed the belief ( $2 d$ ) that the revised formula "will be of particular assistance to States with limited fiscal resources and will enable these States to make more nearly adequate assistance payments. This will help to more nearly balance the level of assistance made available to needy people in various parts of the country."

\section{Combined Money and Vendor Payments}

Effective October 1, 1958, the Federal maximum share of public assistance includes and permits payments by the State to public assistance recipients for all types of aid including medical care. It eliminates the separate matching of payments to vendors, such as doctors, dentists, nurses, and hospitals, in the fixed Federal maximums of $\$ 6$ per adult recipient and $\$ 3$ per child.

Heretofore, under the 1956 Amendments to the Social Security Act which operated for a little more than a year (from July 1, 1957, to October 1, 1958), assistance payments for medi- 
Table 1. Federal financial participation in public assistance expenditures for States, Territories, and the District of Columbia, October 1, 1958, to June 30, 1961

\begin{tabular}{|c|c|c|c|c|c|}
\hline State & $\begin{array}{l}\text { Federal } \\
\text { partici- } \\
\text { pation } \\
\text { (percent) }\end{array}$ & State & $\begin{array}{l}\text { Federal } \\
\text { partici- } \\
\text { pation } \\
\text { (percent) }\end{array}$ & State & $\begin{array}{l}\text { Federal } \\
\text { partici- } \\
\text { pation } \\
\text { (percent) }\end{array}$ \\
\hline Alabama _.. & 65.00 & Kentucky _. & 65.00 & North Dakota & 65. 00 \\
\hline Alaska. - & 50.00 & Louisiana. - & 65.00 & Ohio & 50.00 \\
\hline Arizona.. & 63.23 & Maine ..... & 65.00 & Oklahoma. & 65. 00 \\
\hline Arkansas. & 65.00 & Maryland & 50. 00 & Oregon $\ldots \ldots$ & 52.58 \\
\hline California_ & 50.00 & Massachusetts . & 50.00 & Pennsylvania & 50.00 \\
\hline Colorado & 53. 42 & Michigan_...... & 50.00 & Rhode Island & 50.00 \\
\hline Connecticut & 50.00 & Minnesota... & 58.57 & South Carolina. & 65.00 \\
\hline Delaware & 50.00 & Mississippi & 65. 00 & South Dakota.......... & 65. 00 \\
\hline District of Columbia & 50.00 & Missouri & 53. 42 & Tennessee . . . . . . . . . & 65. 00 \\
\hline Florida & 59.68 & Montana & 54.07 & Texas . . .......... & 61. 36 \\
\hline Georgia_..... & 65.00 & Nebraska_... & 63. 41 & Utah....... & 65. 00 \\
\hline Hawaii. .... & 50.00 & Nevada & 50.00 & Vermont & 65. 00 \\
\hline Idaho & 65. 00 & New Hampshire $\ldots . . .$. & 57.91 & Virginia . . . . & 65.00 \\
\hline Illinois . . . & 50.00 & New Jersey _. . . . . . . . & 50.00 & Washington $\ldots \ldots$ & 50.00 \\
\hline Indiana & 50.00 & New Mexico & 65.00 & West Virginia. & 65.00 \\
\hline Iowa & 63. 23 & New York $\ldots$ & 50.00 & Wisconsin & 54. 60 \\
\hline Kansas $_{\ldots} \ldots$ & 60.78 & North Carolina..... & 65.00 & Wyoming ............... & 50. 92 \\
\hline
\end{tabular}

Source: Reference 3.

cal care were made by States either directly to recipients or to recipients and vendors combined or to vendors directly on behalf of a needy person, within fixed limits to which the Federal funds could be applied.

The types of medical care covered included practitioners' services, hospitalization, drugs, nursing-convalescent home care, dental services, nursing services, clinic services, prosthetic appliances, ambulance or other transportation, laboratory, and $\mathrm{X}$-ray services.

A comparison of January 1957 with January 1958 shows that in each of the four programs using public assistance medical care (old-age assistance, aid to dependent children, aid to the blind, and aid to the permanently and totally disabled), the number of States using the vendor method of payment for medical services increased in all but one of the types of medical care: nursing homes for the aged and for the disabled (5). For the same period, the total amount of all vendor payments increased also, but the number of cases for which only vendor payment was made decreased.

Table 2 compares the amount of vendor payments for medical care and the number of cases in which vendor payments only were made for January 1957 (under the old system of com-

Table 2. Number of cases receiving only vendor medical payments and amount of vendor medical payments for two selected months, January 1957 and January 1958

\begin{tabular}{|c|c|c|c|c|}
\hline \multirow{2}{*}{ Program } & \multicolumn{2}{|c|}{ January 1957} & \multicolumn{2}{|c|}{ January 1958} \\
\hline & $\begin{array}{l}\text { Number } \\
\text { of cases }\end{array}$ & $\begin{array}{c}\text { Vendor } \\
\text { payments }\end{array}$ & $\begin{array}{l}\text { Number } \\
\text { of cases }\end{array}$ & $\begin{array}{c}\text { Vendor } \\
\text { payments }\end{array}$ \\
\hline Total_... & 20,381 & $\$ 17,567,727$ & 8,973 & $\$ 19,740,122$ \\
\hline $\begin{array}{l}\text { Old-age assistance } \\
\text { Aid to dependent children } \\
\text { Aid to the blind } \\
\text { Aid to the permanently and totally disabled }\end{array}$ & $\begin{array}{r}15,927 \\
884 \\
397 \\
3,173\end{array}$ & $\begin{array}{r}12,723,559 \\
2,196,307 \\
354,684 \\
2,293,177\end{array}$ & $\begin{array}{r}6,874 \\
371 \\
163 \\
1,565\end{array}$ & $\begin{array}{r}13,223,462 \\
3,719,123 \\
455,626 \\
2,341,911\end{array}$ \\
\hline
\end{tabular}

Source: Reference 5. Rased on tables 2 and 5, prepared by the Division of Program Statistics and Analysis, Bureau of Public Assistance, Social Security Administration. 
bined money-vendor payments within the specified maximum) and for January 1958 (under the provisions in effect from July 1, 1957, to October 1, 1958, which permitted a choice of the old system or the separate Federal matching vendor program).

Federal participation in direct payments to vendors was first made possible under the 1950 Social Security Amendments (6,7). The amount, however, for medical care in which the Federal Government could participate had to remain within the specified individual matchable assistance payment maximums.

Table 3 gives the total State and Federal vendor payment for medical care from 1951 through 1957, and a breakdown into the categories of use : old-age assistance, aid to dependent children, to the blind, and to the permanently and totally disabled, and general assistance. The increase in vendor medical payments is the result of several factors, among which are the increase in the cost of medical care and the increase in the number of States providing medical care and thus participating in Federal funds.

A pooled fund (in effect a prepayment monthly arrangement per recipient) was used by public assistance agencies within some States to permit greater flexibility in individual medical care cases. The averaging of costs made possible through the pooled fund arrangement helped to some extent to meet increasing medical needs and costs. The funds available for medical care for needy persons were limited, and only a few States took advantage of Federal contributions to offset such costs.

In fiscal year 1957, only about 10 percent ( $\$ 288$ million) of the total $\$ 3$ billion expended for public assistance went to vendors directly. About 20 percent of the $\$ 288$ million, or 2 percent of the total came from Federal funds. Most vendor payments were made by a few States with the greatest resources. For example, more than half of the vendor payments for aged persons in June 1956 were made in three States: New York, Illinois, and Massachusetts. A few States made vendor payments entirely from State and local funds $(8)$.

To increase funds for medical care for the needy, the Social Security Act was amended again in 1956 (9), effective July 1, 1957, fixing Federal matching maximums for medical care at $1 / 2$ the product of $\$ 6$ times the number of adult recipients and $1 / 2$ the product of $\$ 3$ times the number of child recipients per month. This provision for fixed Federal matching for medical vendor payments was supported by many professional and medical organizations.

Before the 1956 Amendments were put into effect, and because the new fixed maximum vendor payments would penalize some States, new legislation was passed in July 1957 (10). Under the legislation, it was optional with a State whether it use the combined money-vendor payments within the specified maximum or whether it claim separate Federal matching for vendormedical care payments. Only two States, Illi-

Table 3. Total vendor payments for medical care and distribution by categories of use for fiscal years 1951-57 (in thousands)

\begin{tabular}{|c|c|c|c|c|c|c|}
\hline \multirow[b]{2}{*}{ Fiscal year } & \multirow[b]{2}{*}{ Total } & \multicolumn{5}{|c|}{ Category of use } \\
\hline & & $\begin{array}{c}\text { Old-age } \\
\text { assistance }\end{array}$ & $\begin{array}{l}\text { Aid to } \\
\text { dependent } \\
\text { children }\end{array}$ & $\begin{array}{l}\text { Aid to } \\
\text { the blind }\end{array}$ & $\begin{array}{l}\text { Aid to the } \\
\text { permanently } \\
\text { and totally } \\
\text { disabled }\end{array}$ & $\begin{array}{c}\text { General } \\
\text { assistance }\end{array}$ \\
\hline $\begin{array}{l}19511952 \\
1953 \\
195556 \\
1957\end{array}$ & $\begin{array}{r}\$ 100,745 \\
119,147 \\
154,357 \\
175,436 \\
211,799 \\
252,578 \\
288,005\end{array}$ & $\begin{array}{r}\$ 35,860 \\
51,859 \\
73,864 \\
87,406 \\
104,588 \\
130,514 \\
155,935\end{array}$ & $\begin{array}{l}\$ 9,940 \\
11,067 \\
14,433 \\
15,561 \\
19,005 \\
23,034 \\
26,845\end{array}$ & $\begin{array}{l}\$ 954 \\
1,513 \\
2,145 \\
2,489 \\
2,865 \\
3,431 \\
4,330\end{array}$ & $\begin{array}{r}\$ 1,362 \\
6,082 \\
11,532 \\
15,290 \\
19,167 \\
23,869 \\
27,549\end{array}$ & $\begin{array}{r}\$ 52,629 \\
48,626 \\
52,383 \\
54,690 \\
66,174 \\
71,731 \\
73,347\end{array}$ \\
\hline
\end{tabular}

Sodrce: Assistance Analysis Branch, Division of Program Statistics and Analysis, Bureau of Public Assistance, Social Security Administration, October 1958. 
Table 4. Computation of Federal sharing for public assistance under old and new formulas, per recipient ${ }^{1}$

Type of payment

Old formula: separate vendor payments ${ }^{2}$

\begin{tabular}{|c|c|c|c|c|}
\hline & \multirow{2}{*}{ State A } & \multirow[b]{2}{*}{ State B } & \multirow[b]{2}{*}{ State C } & \multirow[b]{2}{*}{ State D } \\
\hline & & & & \\
\hline $\begin{array}{l}\text { Money payments (total) } \\
\text { Number recipients. } \\
\text { Average money payment }\end{array}$ & $\begin{array}{r}\$ 79,650 \\
1,000 \\
\$ 79.65\end{array}$ & $\begin{array}{r}\$ 47,450 \\
1,000 \\
\$ 47.45\end{array}$ & $\begin{array}{r}\$ 81,600 \\
1,000 \\
\$ 81.60\end{array}$ & $\begin{array}{r}\$ 29,670 \\
1,000 \\
\$ 29.67\end{array}$ \\
\hline $\begin{array}{l}\text { Vendor payments (total) } \\
\text { Number recipients. } \\
\text { Average vendor payment }\end{array}$ & $\begin{array}{r}\$ 20,100 \\
1,000 \\
\$ 20.10\end{array}$ & $\begin{array}{r}\$ 6,000 \\
1,000 \\
\$ 6.00\end{array}$ & $\begin{array}{r}\$ 18,150 \\
1,000 \\
\$ 18.15\end{array}$ & (n) \\
\hline $\begin{array}{l}\text { Federal maximums: } \\
\text { Money payments excess } \$ 60 \text { per recipient (total) } \\
\text { Number recipients... } \\
\text { Average excess. }\end{array}$ & $\begin{array}{r}\$ 32,200 \\
1,000 \\
\$ 32.20\end{array}$ & 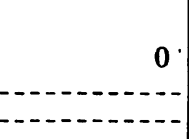 & $\begin{array}{r}\$ 32,200 \\
1,000 \\
\$ 32.20\end{array}$ & $\ldots$ \\
\hline $\begin{array}{l}\text { Average per recipient within Federal maximum: } \\
\text { Money payment... } \\
\text { Vendor payment. }\end{array}$ & $\begin{array}{r}3 \$ 47.45 \\
\$ 6.00\end{array}$ & $\begin{array}{r}4 \$ 7.45 \\
\$ 6.00 \\
\end{array}$ & $\begin{array}{r}349.40 \\
\$ 6.00\end{array}$ & $\begin{array}{r}4 \$ 29.67 \\
0\end{array}$ \\
\hline Total & $\$ 53.45$ & $\$ 53.45$ & $\$ 55.40$ & $\$ 29.67$ \\
\hline $\begin{array}{l}\text { Federal share: } \\
\text { Money payment: } \\
\quad 1 / 5 \text { first } \$ 30 \\
1 / 2 \text { balance. }\end{array}$ & $\begin{array}{l}\$ 24.00 \\
\text { s } \$ 8.72\end{array}$ & $\begin{array}{l}\$ 24.00 \\
5 \$ 8.72\end{array}$ & $\begin{array}{l}\$ 24.00 \\
5 \$ 9.70\end{array}$ & $\begin{array}{r}\$ 23.74 \\
0\end{array}$ \\
\hline Total & $\$ 32.72$ & $\$ 32.72$ & $\$ 33.70$ & $\$ 23.74$ \\
\hline $\begin{array}{l}\text { Vendor payment: } \\
1 / 2 \$ 6\end{array}$ & $\$ 3.00$ & $\$ 3.00$ & $\$ 3.00$ & \\
\hline Total & $\$ 35.72$ & $\$ 35.72$ & $\$ 36.70$ & $\$ 23.74$ \\
\hline
\end{tabular}

New formula: money and vendor payments combined ${ }^{\circ}$

\begin{tabular}{|c|c|c|c|}
\hline State A ${ }^{7}$ & State B 8 & State $\mathbf{C}^{9}$ & State $D^{8}$ \\
\hline $\begin{array}{l}\$ 79,650 \\
\$ 20,100\end{array}$ & $\begin{array}{r}\$ 47,450 \\
\$ 6,000\end{array}$ & $\begin{array}{l}\$ 81,600 \\
\$ 18,150\end{array}$ & $\begin{array}{r}\$ 29,670 \\
0\end{array}$ \\
\hline $\begin{array}{r}\$ 99,750 \\
1,000 \\
\$ 99.75\end{array}$ & $\begin{array}{r}\$ 53,450 \\
1,000 \\
\$ 53.45\end{array}$ & $\begin{array}{r}\$ 99,750 \\
1,000 \\
\$ 99.75\end{array}$ & $\begin{array}{r}\$ 29,670 \\
1,000 \\
\$ 29.67\end{array}$ \\
\hline$\$ 65.00$ & $\$ 53.45$ & $\$ 65.00$ & $\$ 29.67$ \\
\hline $\begin{array}{r}\$ 24.00 \\
10 \$ 20.82 \\
\end{array}$ & $\begin{array}{r}\$ 24.00 \\
11 \\
\$ 15.24 \\
\end{array}$ & $\begin{array}{r}\$ 24.00 \\
12 \$ 17.50\end{array}$ & $\begin{array}{r}\$ 23.74 \\
0\end{array}$ \\
\hline$\$ 44.82$ & $\$ 39.24$ & $\$ 41.50$ & $\$ 23.74$ \\
\hline$+\$ 9.10$ & $+\$ 3.52$ & $+\$ 4.80$ & 0 \\
\hline
\end{tabular}

1 Calculations based on table 4, Explanation of 1958 Amendments, Social Security Administration, Bureau of Public Assistance, September 1958 (mimeographed). ${ }^{2}$ In effect until October 1, 1958. 8 Average money payment minus average excess. "Same as average money payment. ${ }^{5}$ One-half the difference between the average Federal maximum money payment and first $\$ 30$. ${ }^{6}$ Effective October $1,1958 .{ }^{7}$ Federal percentage based on per capita income: 59.5 percent. ${ }^{8}$ Federal percentage: 65 percent. ${ }^{\circ}$ Federal percentage: 50 percent. 1059.5 percent of $\$ 35$ difference between amount within Federal maximum and first $\$ 30$. ${ }^{11} 65$ percent of $\$ 23.45$ difference. 1250 percent of $\$ 35$ difference. 
nois and New Hampshire, chose to continue using the old system of combined payments within the specified maximum, for selected adult programs. Illinois continued it for the aged, blind, and disabled payments, and New Hampshire for the aged and disabled.

However, separate Federal matching for vendor medical payments did not allow the States sufficient flexibility in providing medical care for the needy, and was eliminated with the 1958 legislation. In place of a money payment maximum of $\$ 60$ and a maximum of $\$ 6$ per vendor medical care payments for adults, and $\$ 32$ and $\$ 3$ respectively for children, there is an average maximum for all public assistance (including medical care payments) of $\$ 65$ for adults and $\$ 30$ for children in which the Federal Government participates.

Table 4 compares the method of computation of Federal sharing under the old formula in effect until October 1, 1958 (separate money and vendor medical payments), and under the 1958 amendment (combined money and vendor medical payments), effective October 1, 1958.

The 1958 amendment gives the State greater flexibility in allocating funds for medical care between recipients and vendors without loss in Federal funds. The decision on method of payment for medical care can rest on the State's determination of what is best for the recipient and for its own administration.

Under the new amendment, medical care payments are still available to puolic assistance recipients, with Federal participation, but the amount and method of payment are determined by the needs of the State rather than by the policy of the Federal Government. A person whose income is sufficient to meet all but medical needs can be counted as a recipient for the total public assistance average in which the Federal Government will participate, if he is also established as a case of need, under the standards of assistance of each State. That is, States may now get the higher Federal matching provided for the first fraction ( $4 / 5$ of $\$ 30$ for adults and $14 / 17$ of $\$ 17$ for children) in cases receiving vendor medical payments only, provided that a State has validly established that these persons are eligible for public assistance.

According to the House Report (2e), "This change will enable a State to decide to what extent it wishes to pay for medical care received by the needy through the method of making a payment in his behalf to the vendor of the medical care or giving him money so that he can purchase his own medical care, without being influenced by consideration of Federal financial sharing."

An Advisory Council on Public Assistance, appointed by the Secretary of Health, Education, and Welfare, has been established to review the existing public assistance programs in relation to old-age, survivors, and disability insurance, the fiscal capacities of the States and the Federal Government, and any other factors relating to the amount and proportion of State and Federal sharing in the public assistance program (1c). It is to be composed of the Commissioner of Social Security and 12 other persons, including employer and employee representatives and experts in State and Federal administrative and fiscal programs. It is to report back to the Secretary not later than January 1, 1960.

\section{Maternal and Child Welfare}

Maternal and child health services, crippled children's services, and child welfare services (the three grant programs covered by title V of the law) have all received substantial increases in annual authorized appropriations, and to that extent the changes are significant for the national health outlook. The increases in annual amounts authorized are as follows: maternal and child health services, from $\$ 16$,500,000 to $\$ 21,500,000$ (30.3 percent) ; crippled children's services, from $\$ 15,000,000$ to $\$ 20$,000,000 ( 33.3 percent) ; and child welfare services, from $\$ 12,000,000$ to $\$ 17,000,000 \quad(41.7$ percent).

Certain child welfare provisions in the old law have been eliminated. Provisions specifying the use of Federal child welfare funds in predominantly rural areas or other areas of special need have been set aside; services are now extended to urban and rural children on the same basis.

According to the House Report ( $2 f)$, "Many families have shifted in the last decade from farms and small towns to cities where services have not expanded to meet their needs. In the light of these developments, your committee 
believes that the present law should be amended so as to make child welfare services generally available not only in rural areas but also in urban areas and to give equal consideration to children in urban areas as to children in rural areas."

This change does away with inequities in the prior law, since 3 out of 5 children in the Nation now live in urban areas, and the rural-to-urban shift in population continues.

The allotment formula has been modified accordingly, so that allotments of child welfare funds will be in direct proportion to the total population under 21 years of age and in inverse proportion to State per capita income, with the protective proviso that no State shall receive less than it would have prior to the amendments of 1958 under an appropriation of $\$ 12,000,000$. Previously, allotment was primarily on the basis of rural child population under the age of 18. Furthermore, the new statute requires that Federal child welfare funds be matched with State and local funds beginning with fiscal 1960. Heretofore States were required to pay "part of the cost" for services in predominantly rural areas.

The Children's Bureau, beginning with the nationwide conference of State public welfare administrators, held early in October 1958, is giving special help to the State agencies in regard to the amendments, particularly as they affect the extension of services to urban areas (11). The Federal share and the allotment percentage for each State under the new formula has been published in the Federal Register (12). The Handbook for Child Welfare Services has already been revised to reflect the changes in Federal policy produced by the amendments which are now in effect.

An Advisory Council on Child Welfare Services has also been established, under the amendments, to make recommendations to the Secretary of Health, Education, and Welfare on the effective extension of child welfare services beyond rural areas. It is also to be composed of 12 members, appointed by the Secretary, and representing voluntary, civic, religious, and professional welfare organizations and the public $(1 d)$. It is to report its findings and recommendations not later than January 1,1960 .

\section{Hospitalization for OASI Beneficiaries}

The House Ways and Means Committee, in its report on the Social Security Amendments of 1958, took cognizance of the needs of the aged for hospital and nursing services. It referred to the various bills introduced into the 85th Congress that would broaden the old-age, survivors, and disability insurance program to provide payment for such services to OASI beneficiaries. In its public hearings on social security ( $2 g$ ), the committee heard testimony to the effect that "under existing arrangements, insurance against the costs of needed hospital and nursing home services is out of reach of many older people," and concluded that "there appears to be a need for making this protection available to older people."

However, the committee believed that before legislation could be considered or recommendations entertained, a study of the practicability and costs and of alternative methods of providing such protective insurance to OASI beneficiaries was needed. The alternatives, the committee held, should include a possible prepayment plan whereby a worker, during his years of employment, could make additional social security contributions which would be used to buy hospital and nursing care insurance from private and nonprofit health insurance organizations. For each of the alternatives considered in the study, there should be an evaluation of the cost of the benefits and the administrative implications.

The committee asked the Secretary of Health, Education, and Welfare to conduct such a study and report back to Congress by February 1,1959 .

\section{Summary}

The Social Security Amendments of 1958 provide for a revision of the financial structure of the OASI program through increased benefits and an increase in the maximum earnings tax base. They also provide for improvements in the protection of disabled OASI recipients.

In public assistance, new principles of average maximum matchable payments and variable grants based on per capita income have been introduced. Separate matching for ven- 
dor medical payments has been eliminated. An advisory council has been established to review existing public assistance programs, and the fiscal capacities of State and Federal Governments with respect to the public assistance program.

For the three programs under title $\mathrm{V}$ of the Social Security Act (maternal and child health, crippled children's, and child welfare services), increased annual appropriations have been authorized.

In child welfare, financial allotments on the basis of the rural child population have been eliminated, and services will now be extended to urban and rural children on the same basis. Beginning with fiscal 1960, Federal child welfare funds will be matched with State and local funds. An advisory council has been established to make recommendations on the effective extension of child welfare services beyond the rural areas.

The House Ways and Means Committee requested the Department of Health, Education, and Welfare to study the hospital and home nursing needs of the aged OASI beneficiaries. The study is to include practicability and costs of protective insurance and alternative methods of providing it. The study is to be completed by February 1, 1959, and made available to Congress.

\section{REFERENCES}

(1) Public Law 85-840 (H. R. 13549), 72 Stat. 1013, (a) Title I-VII; (b) Title IV, Sec. 401a-c; (c) Title VII, Sec. 704a-d; (d) Title VII, Sec. 705a-d.
(2) U. S. Congress House Committee on Ways and Means: Social Security Amendments of 1958. Report No. 2288 (85th Cong., 2d Sess.). Washington, D. C., U. S. Government Printing Office, 1958, (a) p. 4; (b) p. 10 ; (c) p. 5; (d) pp. $40-41$; (e) p. 40 ; $(f)$ pp. $43-44$; $(g)$ p. 6 .

(3) U. S. Social Security Administration: State assistance expenditures. Federal percentage. 23 Fed. Reg. 7150 (1958).

(4) U. S. Social Security Administration Division of Program Research: Total and per capita personal income, 1957. Research and Statistics Note No. 30, Sept. 12, 1958. Washington, D. C., 1958. Mimeographed.

(5) U. S. Bureau of Public Assistance: Medical care in public assistance: Information relating to changes, early 1957 to January 1958. State Letter No. 333, April 8, 1958. Washington, D. C., 1958. Mimeographed.

(6) Mushkin, S. J.: Medical services and the Social Security Amendments of 1950. Pub. Health Rep. 66 : 98-114, Jan. 26, 1951.

(7) Dearing, W. P.: Medical care for public assistance recipients. Pub. Health Rep. 66 : 89-97, Jan. 26, 1951.

(8) U. S. Department of Health, Education, and Welfare: Annual report for 1957. Bureau of Public Assistance Reprint. Washington, D. C. U. S. Government Printing Office, 1958, pp. 5-7.

(9) Public Law 880, 84th Cong., 2d Sess., 70 Stat. 807.

(10) Public Law 85-110, 71 Stat. 308.

(11) U. S. Department of Health, Education, and Welfare: How the principal new or expanded programs of the Department of Health, Education, and Welfare will be put into operation. Memorandum released at Secretary's conference, September 10, 1958. Washington, D. C., 1958. Mimeographed.

(12) U. S. Social Security Administration: Promulgation of Federal shares and allotment percentages for purposes of child welfare services under title V, part 3, of the Social Security Act, as amended. 23 Fed. Reg. 7332 (1958). 